\title{
Reproductive biology and recruitment of Xiphopenaeus kroyeri in a marine protected area in the Western Atlantic: implications for resource management
}

\author{
Ariádine C. Almeida' ${ }^{1, *}$, J. Antonio Baeza ${ }^{2,3,4}$, Vivian Fransozo ${ }^{1,5}$, Antonio L. Castilho ${ }^{1}$ \\ Adilson Fransozo ${ }^{1}$ \\ ${ }^{1}$ NEBECC (Crustacean Biology, Ecology and Culture Study Group), Departamento de Zoologia, Instituto de Biociências, \\ Universidade Estadual Paulista, Botucatu, São Paulo 18618-970, Brazil \\ ${ }^{2}$ Department of Biological Sciences, Old Dominion University, Norfolk, Virginia 23435, USA \\ ${ }^{3}$ Smithsonian Marine Station at Fort Pierce, Fort Pierce, Florida 34949, USA \\ ${ }^{4}$ Departamento de Biología Marina, Facultad de Ciencias del Mar, Universidad Católica del Norte, Larrondo 1281, \\ Coquimbo, Chile \\ ${ }^{5}$ Instituto Federal de Educação, Ciência e Tecnologia Baiano, Santa Inês, Bahia 45320-000, Brazil
}

\begin{abstract}
The potential of a recently established marine protected area (MPA) in the Western Atlantic, Brazil, as a 'seed production' and nursery ground for Xiphopenaeus kroyeri, an intensively exploited penaeid shrimp, was investigated in an attempt to reveal any future benefit of this new MPA to adjacent populations experiencing heavy exploitation. Overall, we observed that males and females $>12$ and $20 \mathrm{~mm}$ carapace length, respectively, contributed the most to reproduction in the studied population. Reproductive activity of $X$. kroyeri was continuous at the MPA; 2 annual reproductive peaks were recorded from March to April and from November to December, which were followed by recruitment events occurring from March to April 2009 and November 2009. Sediment, temperature, and algae and plant biomass floating near the bottom were relevant in driving reproductive activity and recruitment in $X$. kroyeri. The high reproductive potential of the studied population and the occurrence of abundant juveniles throughout the sampling area, indicating the existence of a nursery ground within the region, suggest that this MPA might provide important benefits in the near future. We argue in favor of future long-term studies on the larval dispersion, reproductive biology and ecology of X. kroyeri in MPAs and non-MPAs to construct a base for future management of this species and to aid stock recovery in fishing areas that are heavily exploited.
\end{abstract}

KEY WORDS: Marine protected area $\cdot$ Xiphopenaeus kroyeri $\cdot$ Size at first maturity $\cdot$ Reproductive potential $\cdot$ Nursery ground $\cdot$ Environmental parameters $\cdot$ Stock recovery

\section{INTRODUCTION}

The seabob shrimp Xiphopenaeus kroyeri (Heller, 1862) is largely distributed in the Western Atlantic, from North Carolina (USA) to Santa Catarina (Brazil) (Holthuis 1980), although there are records of its occurrence in Virginia (USA) and Rio Grande do Sul
(Brazil) (D'Incao et al. 2002). This species can reach over $100 \mathrm{~mm}$ in total length and is very abundant at depths $<27$ m (Holthuis 1980, Branco 2005, Costa et al. 2007); therefore, $X$. kroyeri is the subject of a globally important fishery (Gillett 2008). The average global catch of this shrimp has increased considerably during the last 5 decades with captures ranging 
from $6000 \mathrm{t}$ in the 1960s to $42787 \mathrm{t}$ in the 2000s (FAO 2011). From 1960 to 2009, 513785 t ( 51\%) of the total global catch (1013993 t) was extracted from the Brazilian coast (FAO 2011).

In the northern, northeastern, southeastern and southern regions of the Brazilian coast, which were described by Matsuura (1995) as the major fishing grounds, the seabob shrimp is heavily exploited by trawl fishing boats (Vasconcellos et al. 2007, 2011). Vasconcellos et al. (2007) collected information about the status of stocks of Xiphopenaeus kroyeri based on the analysis of time-series landings by artisan fisheries during the period 1980 to 2002. These authors categorized the status of this shrimp as underexploited in the northern region, moderately exploited in the northeastern region, and overexploited in the southeastern and southern regions of Brazil. Furthermore, X. kroyeri is classified as overfished by the Brazilian government because of the high capture rates of specimens from most or all size/ age classes throughout the range of distribution of this species along the coast of Brazil (Ministry of the Environment, Normative Instruction 5, 21 May 2004).

Due to overexploitation in the southeastern and southern regions, the stocks of Xiphopenaeus kroyeri have presented a continuous decrease in landings since the late 1980s (Valentini et al. 1991, D'Incao et al. 2002, IBAMA/CEPSUL 2006, Vasconcellos et al. 2007). Given the economic significance of this species, research on its ecology, population dynamics, and reproduction has vastly increased over the last years (Nakagaki \& Negreiros-Fransozo 1998, Costa et al. 2000, 2007, 2011, Fransozo et al. 2000, 2002, Branco et al. 1999, Branco 2005, Castro et al. 2005, Castilho et al. 2008a, A. L. Castilho et al. unpubl., Simões et al. 2010, Fernandes et al. 2011, Fransozo et al. 2011, Freire et al. 2011, G. S. Heckler et al. unpubl.). The highest abundance of $X$. kroyeri occurs at temperatures $>20^{\circ} \mathrm{C}$ and in areas where the sediment is composed of silt, clay, and fine and very fine sand (e.g. Costa et al. 2000, 2007, 2011, Fransozo et al. 2002, Castilho et al. 2008a, Simões et al. 2010, Freire et al. 2011). Previous studies have demonstrated continuous reproduction and recruitment of $X$. kroyeri throughout the year, temporal variations in sex ratio, and differences in the size at the onset of sexual maturity between males and females (e.g. Nakagaki \& Negreiros-Fransozo 1998, Fransozo et al. 2000, Branco et al. 1999, Branco 2005, Castro et al. 2005, Fernandes et al. 2011, A. L. Castilho et al. unpubl. data, G. S. Heckler et al. unpubl. data). However, all the studies above have been conducted in populations experiencing high fishing pressure.
Additional studies on the population dynamics and reproductive parameters of $X$. kroyeri in protected areas (with low or no fishing) are relevant to guide management of this species throughout its range of distribution.

The aim of this study is to describe the reproductive parameters and recruitment of Xiphopenaeus kroyeri at Fortaleza Bay, located in a recently established marine protected area (MPA) off the southeastern coast of Brazil, in an attempt to reveal any current or future benefit of this new MPA to adjacent populations experiencing heavy exploitation. We studied monthly variation in size at first sexual maturity, reproductive periodicity and recruitment of $X$. kroyeri from November 2008 to December 2009 in this MPA. We also analyzed the relationship between various environmental variables and the abundance of different demographic categories of $X$. kroyeri at the study area to examine the role of environmental conditions in driving reproductive activity and recruitment in this species.

\section{MATERIALS AND METHODS}

\section{Study site}

Fortaleza Bay $\left(23^{\circ} 29^{\prime} 30^{\prime \prime} \mathrm{S}, 45^{\circ} 10^{\prime} 30^{\prime \prime} \mathrm{W}\right)$ is situated in Ubatuba, on the northern coast of São Paulo State, Brazil. Within Fortaleza Bay, 12 sandy beaches are flanked by rocky shores. There is no considerable depth variation within the bay; depths range from 1 to $12 \mathrm{~m}$. Escuro and Comprido rivers, originating from the Atlantic coastal forest (Mata Atlântica), flow into the bay and support a diverse intertidal mangrove ecosystem. Fortaleza Bay was established as an MPA (Área de Proteção Ambiental Marinha do Litoral Norte: Setor Cunhambebe) by Proclamation No. 53525, on 8 October 2008 by the Brazilian Ministry of the Environment in order to prioritize the conservation, preservation and sustainable use of marine resources in the region. In this MPA, fishing is only permitted if it is necessary for the subsistence of traditional human communities as well as amateur and sport fishing. Commercial fishing is not allowed. These actions attempt to protect, ensure and discipline the rational use of resources in the region, promoting sustainable development.

The Ubatuba region is characterized by innumerable spurs of the Serra do Mar mountain chain that form an extremely indented coastline (Ab'Saber 1955). Exchange of water and sediment between the coastal region and the adjacent shelf is very limited 
(Mahiques 1995). This region is affected by 3 water masses: coastal water (CW: temperature $>20^{\circ} \mathrm{C}$, salinity $<36$ PSU), tropical water (TW: $>20^{\circ} \mathrm{C},>36 \mathrm{PSU}$ ) and South Atlantic central water (SACW: $<18^{\circ} \mathrm{C},<36$ PSU) (Castro-Filho et al. 1987, Odebrecht \& Castello 2001). During summer, the SACW penetrates into the bottom layer of the coastal region and forms a thermocline over the inner shelf located at depths of 10 to $15 \mathrm{~m}$. During winter, the SACW retreats to the shelf break and is replaced by the CW. As a result, no stratification is present over the inner shelf during winter months (Pires 1992, Pires-Vanin \& Matsuura 1993). The sediment is composed mainly of silt, clay, and fine and very fine sand given the low water movement within the bay and between the bay and the adjacent continental shelf (Mahiques et al. 1998).

\section{Shrimp sampling and description of environmental conditions}

Based on previous investigations conducted in the study region (see Costa et al. 2007, 2011), Xiphopenaeus kroyeri is very abundant in depths $<20 \mathrm{~m}$. Also, the authors suggest that juvenile individuals are not dependent on estuarine regions, completing their life cycle in shallow coastal areas where both juveniles and adults are largely caught by artisanal fishing boats. Thus, the sampling described below allows capturing all demographic categories (juveniles, adult males and females) of $X$. kroyeri.

Shrimp samples were collected monthly from November 2008 to December 2009 using a fishing boat carrying 2 rig nets $(7.5 \mathrm{~m}$ long, $2.0 \mathrm{~m}$ horizontal mouth opening, 15 and $10 \mathrm{~mm}$ mesh diameter at the body and cod end of the net, respectively). A total of 7 permanent transects were established within Fortaleza Bay (Fig. 1) and sampled monthly. One haul per transect and month was made throughout the sampling period. Each transect was trawled for $1 \mathrm{~km}$ (each haul lasted $\sim 20 \mathrm{~min}$ ) covering a total area of $4 \mathrm{~km}^{2}$ transect ${ }^{-1}$.

During trawling, bottom water samples were taken with a Nansen bottle in each of the different transects. Water temperature and salinity were measured with a mercury thermometer (accuracy: $0.5^{\circ} \mathrm{C}$ ) and an optical refractometer (precision: 0.5 PSU), respectively.

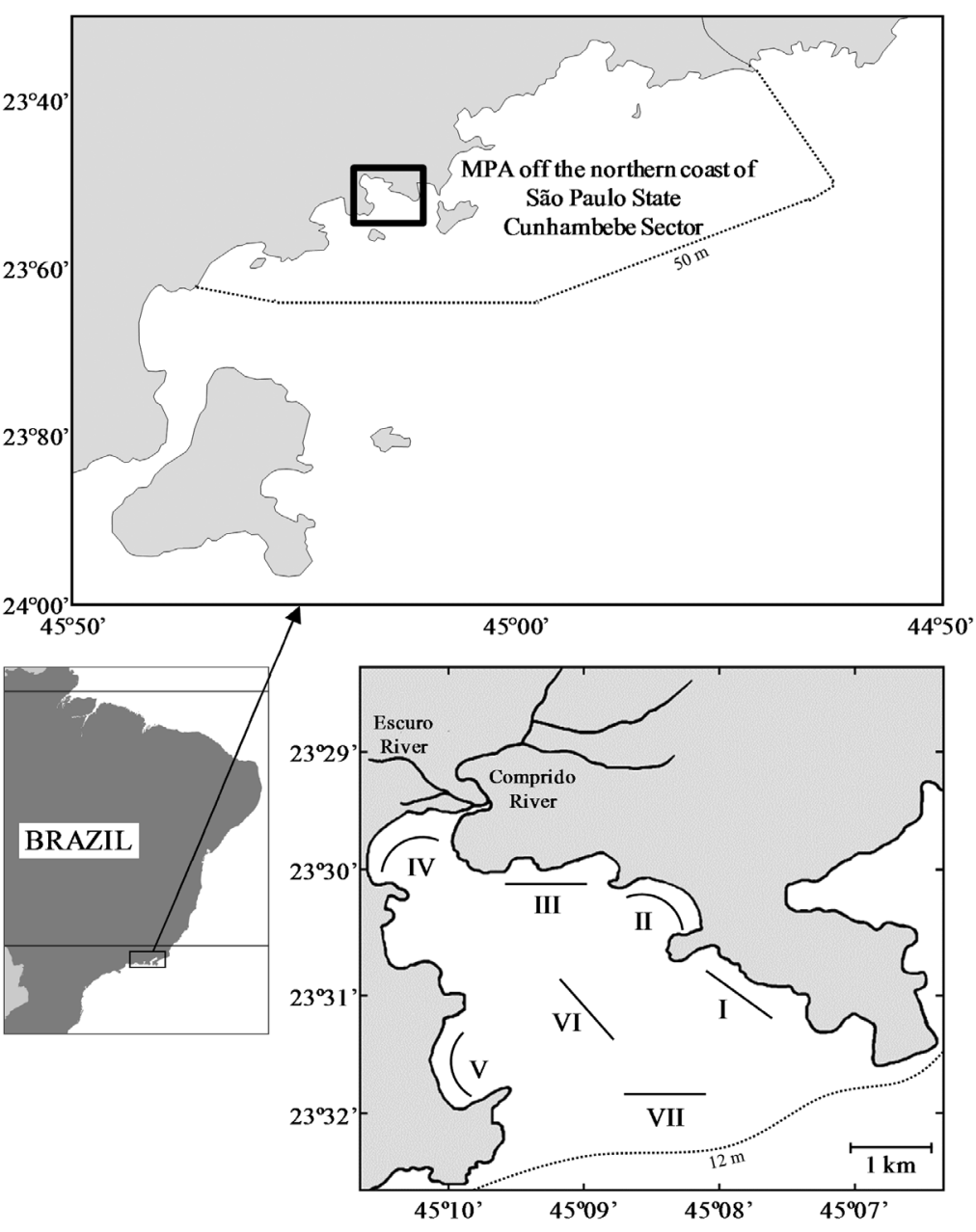

Fig. 1. Marine protected area (MPA) and sampling transects in Fortaleza Bay. Dotted $50 \mathrm{~m}$ line is the MPA boundary; dotted $12 \mathrm{~m}$ line corresponds to the depth range at Fortaleza Bay

Sediment samples were obtained during each month and at each transect with a Van Veen grab $\left(0.025 \mathrm{~m}^{2}\right)$ to analyze sediment grain size composition and organic matter content. Sediment samples were transported to the laboratory and oven-dried at $70^{\circ} \mathrm{C}$ for $48 \mathrm{~h}$. For the analysis of grain size composition, 2 subsamples of $50 \mathrm{~g}$ were treated with $250 \mathrm{ml}$ of $\mathrm{NaOH}$ solution $\left(0.2 \mathrm{~mol} \mathrm{l}^{-1}\right)$ and stirred for $5 \mathrm{~min}$ to release silt and clay particles. Next, the subsamples were rinsed on a $0.063 \mathrm{~mm}$ sieve. Grain size categories followed the Wentworth (1922) American standard, for which sediments were sieved at $2 \mathrm{~mm}$ (for gravel retention); 2.0-1.0 (very coarse sand); 1.0-0.5 (coarse sand); 0.5-0.25 (medium sand); 0.25-0.125 (fine sand) and 0.125-0.063 mm (very fine sand). Smaller particles were classified as silt and clay. The 3 most quantitative important sediment grain size fractions were defined according to Magliocca \& Kutner (1965): Class A sediments in 
which gravel (G), very coarse sand (VCS), coarse sand (CS), and medium sand (MS) account for $>70 \%$ of the sample weight. In Class B, fine sand (FS) and very fine sand (VFS) constitute $>70 \%$ of the sample weight. In Class $\mathrm{C}_{1}>70 \%$ of the sediments are silt and clay $(\mathrm{S}+\mathrm{C})$. Measures of central tendency of the sediment, corresponding to phi values, were calculated using the formula phi $=-\log _{2} d$, where $d=$ grain diameter $(\mathrm{mm})$, in which the following scale was obtained: $-2=$ phi $<-1(\mathrm{G}) ;-1=$ phi $<0(\mathrm{VCS}) ; 0=$ phi $<1(\mathrm{CS}) ; 1=$ phi $<2(\mathrm{MS}) ; 2=$ phi $<3(\mathrm{FS}) ; 3=$ phi $<4$ (VFS); and phi $\geq 4$ (S+C). From this scale, phi values were obtained in order to determine the most frequent grain size fraction in the sediment. These values were calculated from data extracted from cumulative curves of sediment frequency distribution. The values corresponding to the 16th, 50th and 84th percentiles were used to determine the mean diameter $\left(d_{\mathrm{m}}\right)$ using the formula $d_{\mathrm{m}}=\mathrm{phi}_{16}+\mathrm{phi}_{50}+\mathrm{phi}_{84} / 3$ (Suguio 1973). Finally, organic matter content of sediment was estimated as the difference between initial and final ash-free dry wt of 2 subsamples (10 g each) incinerated in porcelain crucibles at $500^{\circ} \mathrm{C}$ for $3 \mathrm{~h}$.

Considerable amounts of algae and plant fragments floating near the marine floor that were retained in the trawl nets during sampling were collected, sorted and the biomass (total wet wt, $\mathrm{kg}$ ) was recorded with a balance $($ precision $=0.01 \mathrm{~g}$ )

\section{Reproductive parameters and recruitment}

We collected a total of 44029 shrimps during the sampling period. Logistic and time constraints did not permit sexing and measuring each collected individual in such a large sample. Thus, we randomly separated a subsample of $250 \mathrm{~g}$ from each sample for analysis. In samples comprising $250 \mathrm{~g}$ or less, all individuals were sexed (presence of petasma in males and thelycum in females, see below) and measured using a caliper to the nearest $0.1 \mathrm{~mm}$. Carapace length $(\mathrm{CL}, \mathrm{mm})$, measured from the orbital angle to the posterior margin of the carapace, was recorded for each shrimp.

Males and females were categorized as juveniles or adults based on macroscopic observations of secondary sexual characters (petasma and thelycum). In males, the endopods of the first pleopods form the petasma. The endopods are completely separated in juveniles but are fused in adults (Bauer 1986, 1991, Fransozo et al. 2011). In females, the thelycum corresponds to any external modification of the posterior thoracic sternites and/or coxae. This structure stores spermatophores transferred by males during insemination. In adult females, the thelycum is a single smooth broad plate and bears an aperture flanked by a transverse ridge that runs from right to left. In immature (juvenile) females, the ridge has a space between the plates (Bauer 1986, 1991, Fransozo et al. 2011).

Reproductive condition of each shrimp was determined by macroscopic examination of terminal ampullae in males and ovaries in females. Terminal ampullae were classified either as spent (Stage I) or developed (Stage II) depending upon the absence or presence of spermatophores contained by these structures, respectively (as in Bauer 1991, Bauer \& Cash 1991, Nakagaki \& Negreiros-Fransozo 1998, Díaz et al. 2002). Maturity of the ovaries was determined based on color and volume of this organ within the cephalothorax of female shrimps. Juvenile females had very thin ovaries lacking any coloration while adult females had thick ovaries varying in color from opaque white to olive green. Ovaries in adult females were also classified as spent (Stage I), if they were opaque white in color and thicker than the juvenile ovaries; developing (Stage II), if they were light green; or developed (near spawning) (Stage III), if they were green to olive green (Bauer \& Rivera Vega 1992, Nakagaki \& Negreiros-Fransozo 1998, Peixoto et al. 2003, Campos et al. 2009).

In the present study, recruitment refers to the smallest individuals (immature stage) vulnerable to fishing gear used. The recruitment was determined monthly by the proportion of juveniles in relation to the total number of adults sampled during study period.

\section{Statistical analysis}

Size at first maturity

Size at first sexual maturity (overall and per month) in males and females was determined using the proportion of juvenile and adult individuals in size classes of $0.5 \mathrm{~mm} \mathrm{CL}$. The procedure used here to estimate sexual maturity was based on fitting the sigmoid logistic curve to the data above (e.g. Pinheiro \& Fransozo 1998). We used the equation $y=1 /\left(1+\mathrm{e}^{\left[-r\left(\mathrm{CL}-\mathrm{CL}_{50}\right)\right]}\right)$, where $y$ is the estimated proportion of adult shrimps, $\mathrm{CL}_{50}$ is the carapace size at the onset of sexual maturity, and $r$ is the coefficient for the slope of the logistic curve. The logistic curve was fitted by least squares to the aforementioned proportions per size class of all the individuals and samples using maximum-likelihood iterations. After 
adjusting the regression model, sexual maturity $\left(\mathrm{CL}_{50}\right)$ was estimated as the size at which $50 \%$ of the males and females reached maturity.

Factors correlating with reproduction and recruitment

We explored whether or not environmental variables correlate with reproductive activity and recruitment in the studied population. Shrimps were separated into 5 demographic categories: juveniles (immature males and females), males with terminal ampullae in Stage I (M-1), and Stage II (M-2), females with ovaries in Stage I (F-1), and reproductive females (females with ovaries in Stage II and III grouped together, F-2). The relationship between temperature, salinity, phi organic matter content of the sediment, algae and plant fragments floating near the bottom and the abundance of the demographic categories was assessed using canonical correspondence analysis (CCA, $\alpha=0.05)$ in the software $\mathrm{R}$ v2.7.1 (R Development Core Team 2008). This analysis computes a combination of scores for the data set with maximum linear correlations, showing the highest explanation levels of the variance in the data set. For interpreting this ordination technique, the canonical coefficients are used, which permit relating variation in the abundance of the different demographic categories to variation in environmental parameters (Ter Braak 1986, Kindt \& Coe 2005). The results of the CCA were plotted in a bi-dimensional graph.

\section{RESULTS}

\section{Reproductive parameters and recruitment}

A total of 7659 individuals of Xiphopenaeus kroyeri were analyzed from a total of 98 hauls $\left(7\right.$ hauls $\left.\mathrm{mo}^{-1}\right)$ taken throughout the sampling period. All specimens were measured and sexed during this study; 2216 juveniles (941 males and 1275 females), 2749 adult males, and 2694 adult females. Both juvenile and adult specimens were caught in all transects. The size ranges, means, and standard deviations of the CL of the specimens analyzed are shown in Table 1.

Macroscopic observations of secondary sexual characters and maturity stage of terminal ampullae (in males) and ovaries (in females) indicated that the smallest body sizes (CL) of adult males and adult females were 11.0 and $12.9 \mathrm{~mm}$, respectively. Taking into account the total number of shrimps collected during the entire sampling period, $\mathrm{CL}_{50}$ was estimated to be $12.8 \mathrm{~mm}$ CL in males and $13.2 \mathrm{~mm}$ CL in females (Fig. 2). During most of the study period, $\mathrm{CL}_{50}$ was greater in females than in males, and varied between 12.1 to $13.6 \mathrm{~mm} \mathrm{CL}$ in males, and between 13.0 and $13.3 \mathrm{~mm}$ CL in females (Fig. 2).

Both in male and female shrimps, the degree of maturity of the terminal ampullae and ovaries, respectively, depended upon body size (Fig. 3). More than $50 \%$ of the males with CL $<12.0 \mathrm{~mm}$ had terminal ampullae in Stage II. The percentage of males with terminal ampullae in Stage II abruptly increased from $70 \%$ in males with CL $\sim 14.0 \mathrm{~mm}$ to $90 \%$ in males with CL $\sim 16.0 \mathrm{~mm}$. Females with ovaries in Stage II and III showed higher percentages ( $\geq 50 \%$ ) when CL was $\sim 20 \mathrm{~mm}$ or greater.

The percentage of males with developed terminal ampullae remained relatively constant and $>50 \%$ throughout the year (Fig. 3). In turn, 2 peaks of reproductive activity during the year were identified for females considering the proportion of females with ovaries in different stages of development. One reproductive peak occurred from March to April 2009 and a second peak was observed from November to December 2009. The lowest percentage of females with ovaries in advanced

Table 1. Xiphopenaeus kroyeri. Size of specimens based on carapace length (CL) after 14 hauls in each transect. $\mathrm{N}=$ number of specimens

\begin{tabular}{|c|c|c|c|c|c|c|c|c|c|c|}
\hline \multirow[t]{3}{*}{ Transect } & \multirow{3}{*}{$\begin{array}{c}\text { Depth } \\
(\mathrm{m}) \\
\text { mean } \pm \mathrm{SD}\end{array}$} & \multirow{3}{*}{$\overline{\mathrm{N}}$} & \multirow{2}{*}{\multicolumn{2}{|c|}{$\begin{array}{l}\text { Juveniles } \\
\text { CL (mm) }\end{array}$}} & \multirow{3}{*}{$\mathrm{N}$} & \multirow{2}{*}{\multicolumn{2}{|c|}{$\begin{array}{l}\text { Males } \\
\text { CL (mm) }\end{array}$}} & \multirow{3}{*}{$\mathrm{N}$} & \multicolumn{2}{|c|}{ Females } \\
\hline & & & & & & & & & $-\mathrm{CL}(\mathrm{n}$ & $\mathrm{am})$ \\
\hline & & & Mean \pm SD & Range & & Mean $\pm \mathrm{SD}$ & Range & & Mean \pm SD & Range \\
\hline I & $9.1 \pm 1.0$ & 286 & $10.9 \pm 2.0$ & $5.4-14.0$ & 474 & $17.1 \pm 2.5$ & $11.1-25.8$ & 379 & $17.7 \pm 3.1$ & $12.9-28.2$ \\
\hline II & $7.2 \pm 1.1$ & 313 & $10.9 \pm 1.9$ & $5.3-13.8$ & 337 & $16.6 \pm 2.8$ & $11.1-25.3$ & 398 & $18.5 \pm 3.5$ & $12.9-31.3$ \\
\hline III & $7.0 \pm 0.9$ & 349 & $10.2 \pm 2.2$ & $4.5-14.2$ & 418 & $17.2 \pm 2.7$ & $11.6-26.6$ & 355 & $18.1 \pm 3.4$ & $13.0-30.6$ \\
\hline IV & $5.6 \pm 0.9$ & 301 & $10.6 \pm 2.1$ & $4.9-14.0$ & 414 & $16.6 \pm 2.7$ & $11.0-25.8$ & 431 & $18.1 \pm 3.7$ & $12.9-35.4$ \\
\hline $\mathrm{V}$ & $7.5 \pm 1.5$ & 304 & $11.3 \pm 1.7$ & $6.1-14.0$ & 233 & $15.8 \pm 2.5$ & $11.0-24.6$ & 310 & $17.2 \pm 2.9$ & $12.9-30.5$ \\
\hline VI & $8.0 \pm 1.1$ & 340 & $10.8 \pm 1.9$ & $5.8-14.4$ & 490 & $16.7 \pm 2.3$ & $11.0-25.0$ & 400 & $17.5 \pm 2.9$ & $13.0-32.9$ \\
\hline VII & $10.4 \pm 1.6$ & 323 & $11.0 \pm 1.9$ & $4.8-14.0$ & 383 & $17.2 \pm 2.8$ & $11.0-25.4$ & 421 & $18.6 \pm 3.5$ & $12.9-31.0$ \\
\hline
\end{tabular}



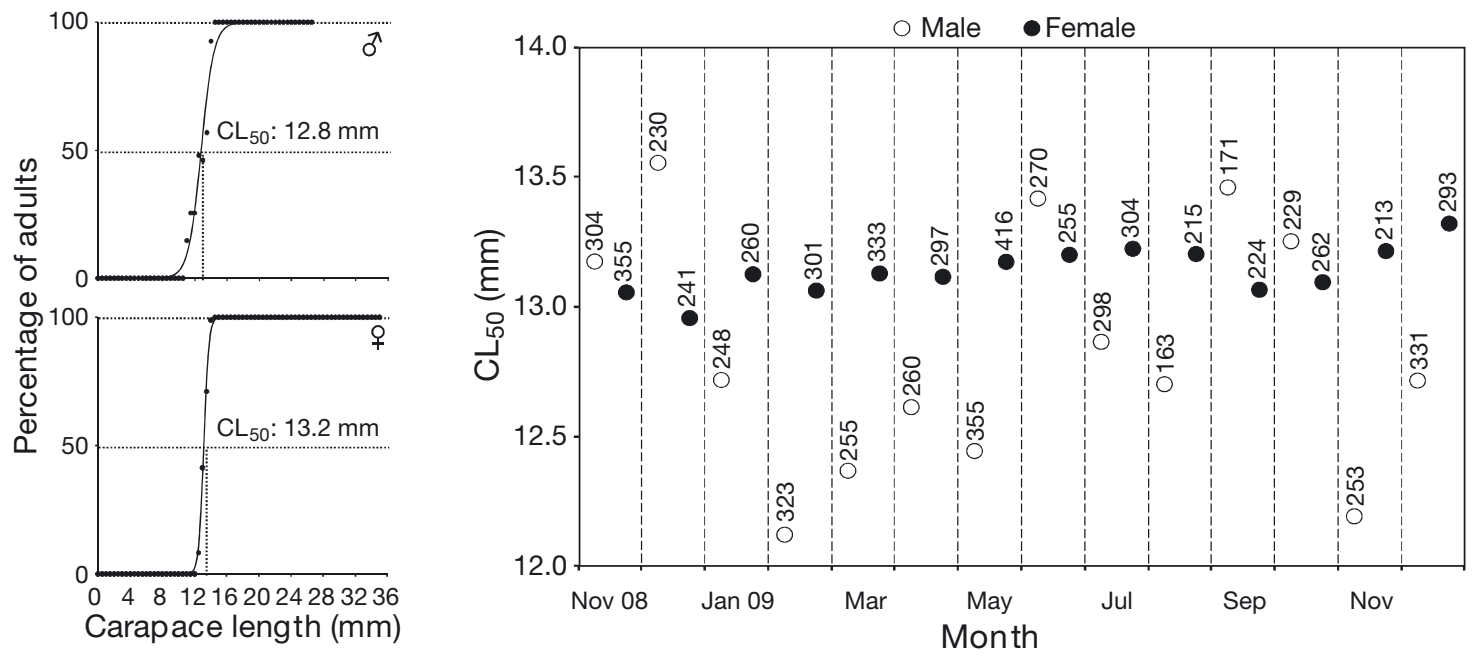

Fig. 2. Xiphopenaeus kroyeri. Overall and monthly sizes at first sexual maturity $\left(\mathrm{CL}_{50}\right)$ for each sex. Right panel: numbers correspond to the no. of specimens analyzed

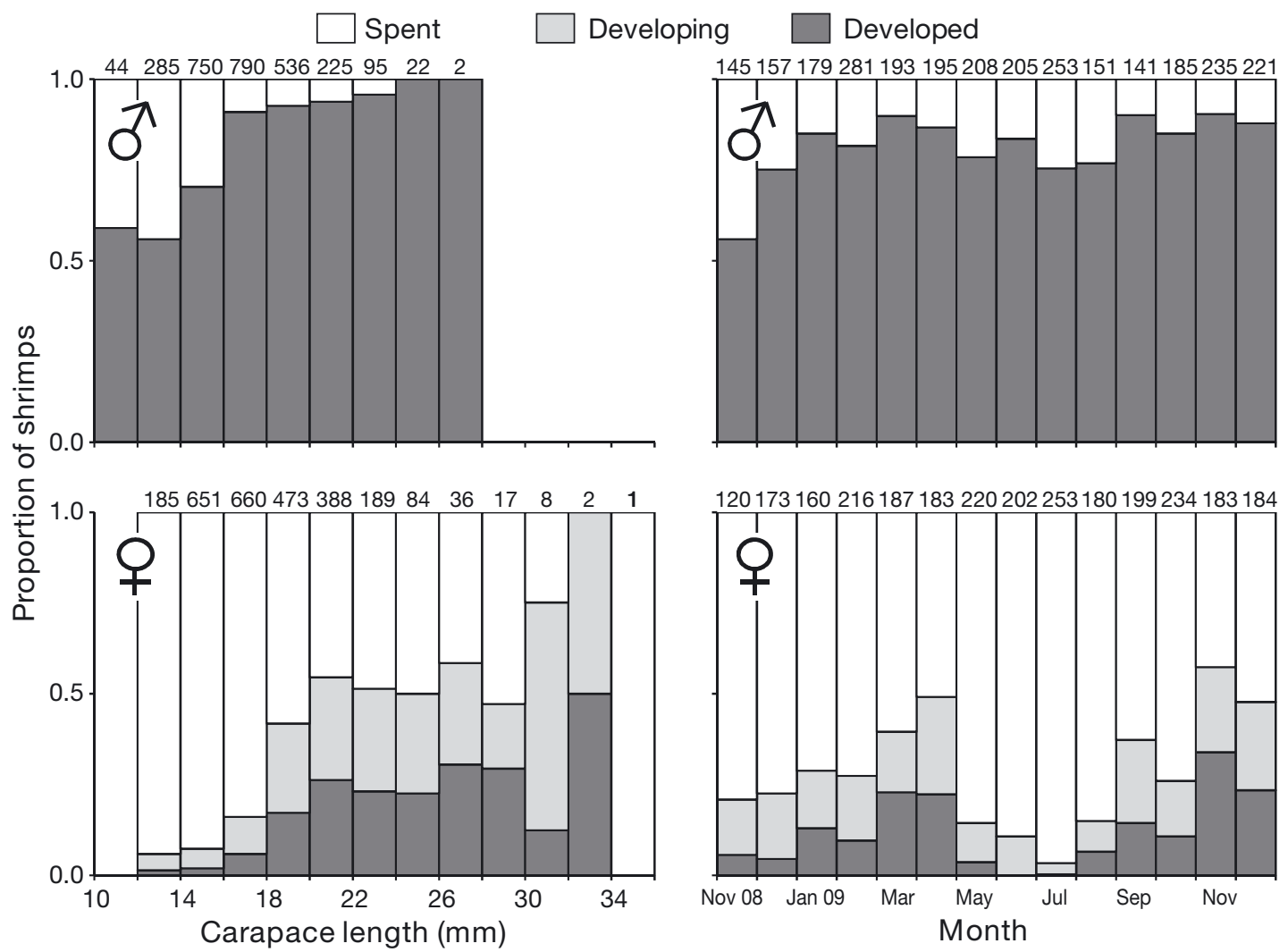

Fig. 3. Xiphopenaeus kroyeri. Proportion of shrimps in developmental stages of terminal ampullae in males and ovaries in females. Numbers above bars are no. of specimens analyzed

stage of development was registered from May to August 2009.

Juveniles were sampled in all transects at Fortaleza Bay, in which mean $( \pm \mathrm{SD})$ depth varied from $5.6 \pm 0.9$ to $10.4 \pm 1.6$ (Table 1 ). The highest and lowest number of specimens were caught from the
Transects III and I, respectively (Table 1). The presence of juveniles was also recorded during all months (Fig. 4). The highest percentages of juveniles (compared to the adults) in the population were observed in November 2008, May 2009, and December 2009 (Fig. 4). These peaks of smaller 


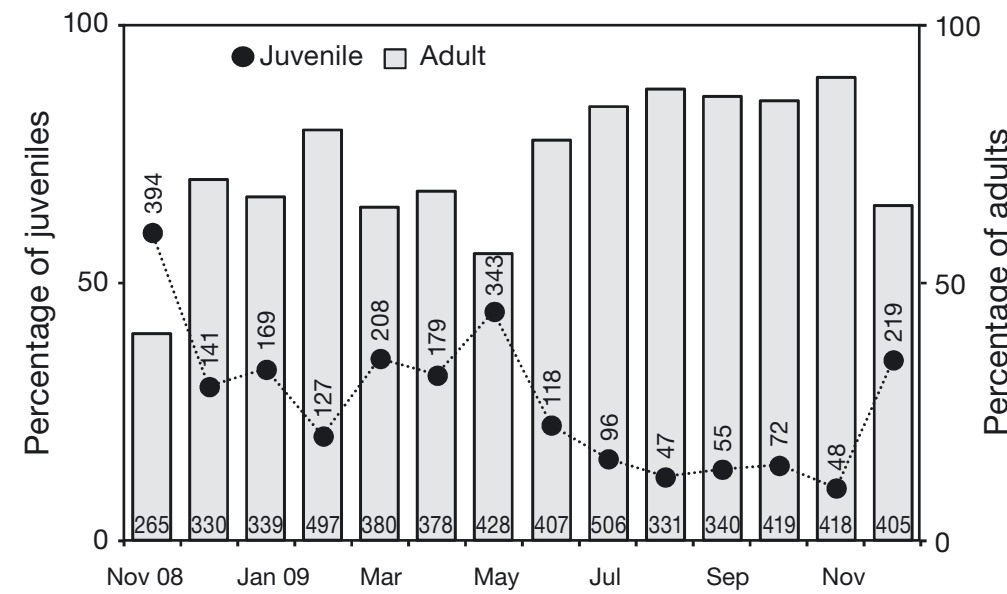

Fig. 4. Xiphopenaeus kroyeri. Monthly variation in the proportion of juveniles compared to adults. Numbers: no. of specimens analyzed

\section{Factors correlating with reproduction and recruitment}

The mean $( \pm \mathrm{SD})$ bottom temperature over the entire study period at Fortaleza Bay was $23.8 \pm 2.1^{\circ} \mathrm{C}$, and varied from $19.7 \pm 1.6$ to $26.3 \pm 1.3^{\circ} \mathrm{C}$. From January to March 2009 temperature increased in the bay followed by a decrease during the following months up to July 2009 (Fig. 5a). The bottom salinity ranged from $31.5 \pm 1.4$ to $36.6 \pm 1.0 \mathrm{PSU}$, with an overall mean of $34.2 \pm 1.6$ PSU. The months from May to July 2009, September and October 2009, showed the lowest mean bottom salinity values (Fig. 5b).

Sediment at Fortaleza Bay was characterized as silt, clay, and fine and very fine individuals are probably indicative of recruitment events, occurring after the main reproductive peaks of Xiphopenaeus kroyeri, which were registered from March to April 2009 and November 2009. The recruitment peak observed in November 2008 might correspond to the previous reproduction peak, not measured in the present study.
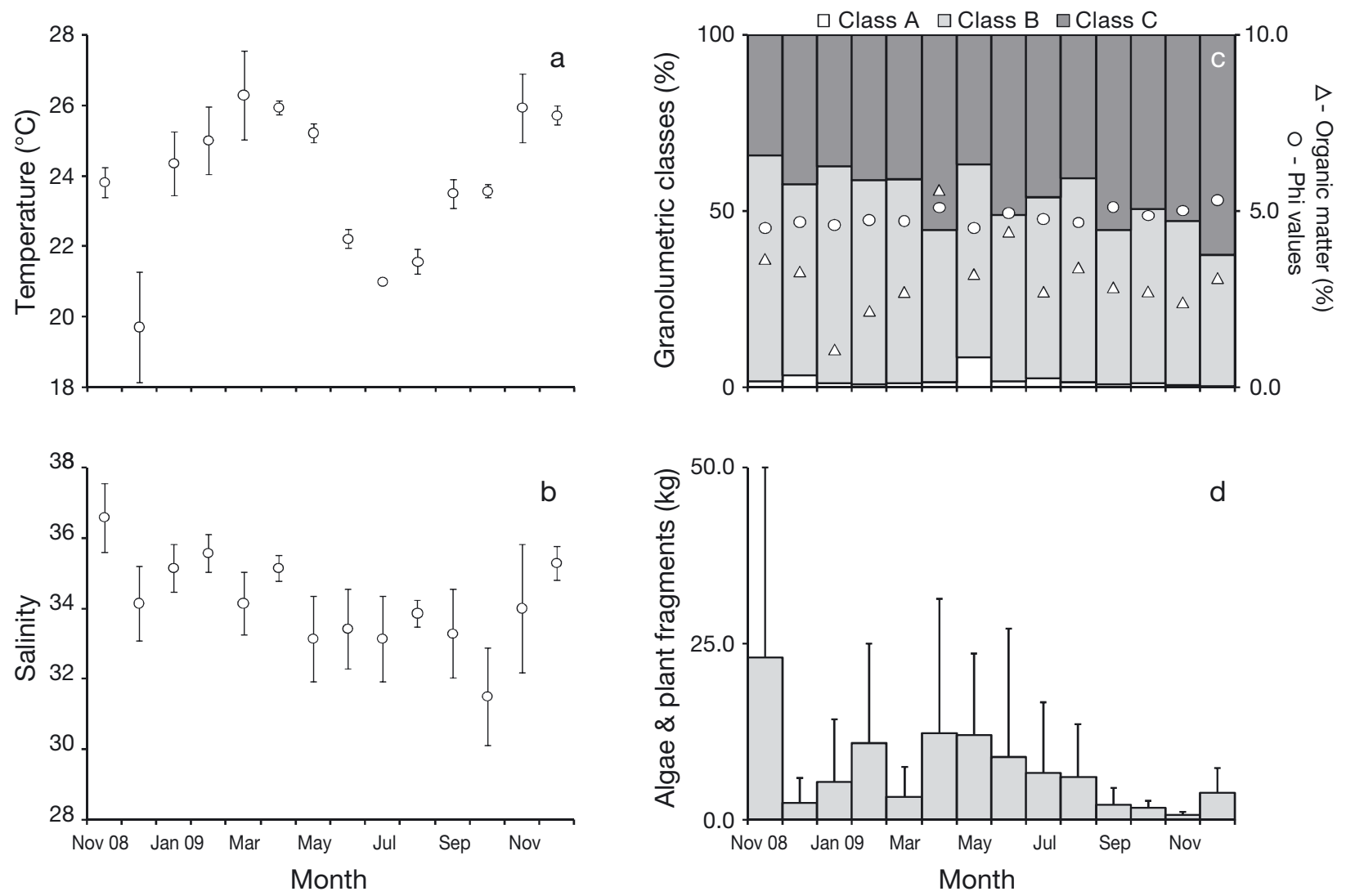

Fig. 5. Monthly mean values $\left(7\right.$ hauls $\left.\mathrm{mo}^{-1}\right)$ of the environmental variables analyzed at Fortaleza Bay during the sampling period. (a) Temperature and (b) salinity of bottom water; (c) granulometric classes A (G, VCS, CS, MS), B (FS, VFS) and C $(\mathrm{S}+\mathrm{C})$; phi values $=$ measures of central tendency of the sediment; $(\mathrm{d})$ mean amount $\left(7\right.$ hauls mo $\left.{ }^{-1}\right)$ of algae and plant fragments 
during April 2009 (5.6\%) and the lowest was observed during January 2009 (Fig. 5c).

The total wet wt of algae and plant fragments floating near the marine floor retained in the trawl nets during sampling showed considerable variability during the study ( $7.1 \pm 6.0 \mathrm{~kg})$ (Fig. 5d). Considering the plant biomass and the variation of the organic matter content and algae throughout sampling period, there was a similar pattern between them from August to December 2009 (Fig. 5c,d).

The CCA used to test for a relationship between environmental variables and abundance of the different demographic categories in Xiphopenaeus kroyeri explained $94 \%$ of the variance in our dataset (Fig. 6). Temperature (CCA, $\mathrm{p}=0.002)$, phi $(\mathrm{p}=$ 0.033 ) and algae and plant fragments floating near the bottom ( $p=0.009)$, all showed a strong correlation with shrimp abundance. On the first axis of the CCA, a positive correlation was observed between the abundance of juveniles and algae and plant fragments floating near the bottom (Table 2, Fig. 6). On the second axis, the abundance of F-2 correlated positively with temperature and phi (a measure of sediment composition) (Table 2, Fig. 6). Overall, the above environmental variables are relevant in explaining abundance of juveniles and adult individuals of $X$. kroyeri.

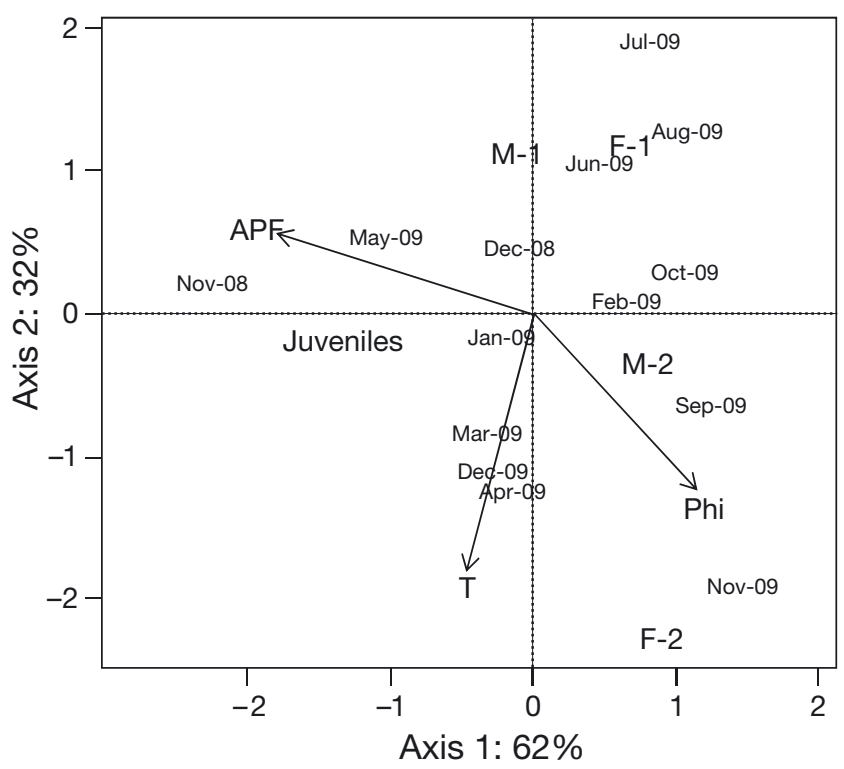

Fig. 6. Xiphopenaeus kroyeri. Canonical correspondence analysis between environmental variables and abundance of demographic categories. Males with terminal ampullae in Stage I (M-1) and Stage II (M-2); females with ovaries in Stage I (F-1) and Stage II+III (F-2); $\mathrm{T}=$ bottom temperature; $\mathrm{APF}=$ amount of algae and plant fragments floating near the marine floor $;$ phi $=$ measure of central tendency of the sediment
Table 2. Xiphopenaeus kroyeri. Results of the Canonical Correspondence Analysis (CCA) ordination for the first 2 canonical axes, with demographic categories and environmental variables data: $\mathrm{T}=$ bottom temperature; $\mathrm{S}=$ bottom salinity; phi = measure of central tendency of the sediment; $\mathrm{OM}=$ organic matter; $\mathrm{APF}=$ algae and plant fragments; males with terminal ampullae in Stage I (M-1) and Stage II (M-2); females with ovaries in Stage I (F-1) and Stage II+III (F-2). $\mathrm{p}=$ significance based on 1000 permutations (Monte Carlo $^{*} \alpha=0.05$ )

\begin{tabular}{|c|c|c|c|c|}
\hline & \multicolumn{2}{|c|}{ Canonical coefficients } & \multirow[t]{2}{*}{$\mathrm{R}^{2}$} & \multirow[t]{2}{*}{$\mathrm{p}$} \\
\hline & Axis 1 & Axis 2 & & \\
\hline \multicolumn{5}{|c|}{ Environmental variables } \\
\hline $\mathrm{T}$ & -0.249 & -0.968 & 0.631 & $0.002^{*}$ \\
\hline $\mathrm{S}$ & -0.845 & -0.535 & 0.410 & 0.069 \\
\hline Phi & 0.712 & -0.703 & 0.487 & $0.033^{*}$ \\
\hline OM & -0.993 & -0.121 & 0.045 & 0.798 \\
\hline $\mathrm{APF}$ & -0.963 & 0.270 & 0.609 & $0.009^{*}$ \\
\hline \multicolumn{5}{|c|}{ Demographic categories } \\
\hline Juvenile & -0.999 & -0.039 & 0.947 & $<0.001^{*}$ \\
\hline M-1 & -0.559 & 0.829 & 0.592 & $0.008^{*}$ \\
\hline M-2 & 0.912 & -0.411 & 0.307 & 0.166 \\
\hline F-1 & 0.261 & 0.965 & 0.782 & $0.001^{*}$ \\
\hline F-2 & 0.294 & -0.956 & 0.963 & $<0.001^{*}$ \\
\hline
\end{tabular}

\section{DISCUSSION}

We have described for the first time the reproductive biology and recruitment of Xiphopenaeus kroyeri in an MPA recently established in the southwestern Atlantic. In the following we discuss 3 important aspects of $X$. kroyeri: (1) size at first maturity, (2) environmental variables that correlate with reproductive peaks and juvenile recruitment, and (3) the existence of nursery grounds in the studied region. We attempt to reveal the possible role that this recently established MPA might play in the management of this exploited shrimp in the near future.

\section{Size at first maturity}

Based on the macroscopic observations of sexual traits, $\mathrm{CL}_{50}$ in Xiphopenaeus kroyeri was estimated to be 12.8 and $13.2 \mathrm{~mm}$ in males and females, respectively. We have reviewed previous studies reporting $\mathrm{CL}_{50}$ in $X$. kroyeri along the Brazilian coast and found considerable variability in this reproductive parameter (e.g. Coelho \& Santos 1993, Branco et al. 1999, Branco 2005, Fernandes et al. 2011, A. L. Castilho et al. unpubl., G. S. Heckler et al. unpubl.; Table 3). Our estimates of $\mathrm{CL}_{50}$ are similar to those reported by G. S. Heckler et al. (unpubl.) and considerably lower 
Table 3. Xiphopenaeus kroyeri. Reproductive parameters of different shrimp populations along the Brazilian coast. NE $=$ northeastern; $\mathrm{SE}=$ southeastern; $\mathrm{S}=$ southern; $\mathrm{PE}=$ Pernambuco; RJ = Rio de Janeiro; SP = São Paulo; SC = Santa Catarina; $\mathrm{CL}_{50}=$ size at first sexual maturity; $\mathrm{Sp}=$ spring; $\mathrm{Su}=$ summer $; \mathrm{Fa}=$ fall $; \mathrm{Wi}=$ winter $;$ na $=$ not available. Reproductive periodicity is continuous for all populations except where not available

\begin{tabular}{|c|c|c|c|c|c|c|}
\hline \multirow[t]{2}{*}{ Coordinates } & \multirow{2}{*}{$\begin{array}{l}\text { Region } \\
\text { (State) }\end{array}$} & \multirow[t]{2}{*}{ Period } & \multicolumn{2}{|c|}{$\mathrm{CL}_{50}(\mathrm{~mm})$} & \multirow{2}{*}{$\begin{array}{l}\text { Reproductive } \\
\text { periodicity }\end{array}$} & \multirow[t]{2}{*}{ Source } \\
\hline & & & $\sigma^{7}$ & q & & \\
\hline $08^{\circ} 45^{\prime} \mathrm{S}, 35^{\circ} 06^{\prime} \mathrm{W}$ & $\mathrm{NE}(\mathrm{PE})$ & May 1986-Dec 1992 & na & 19.8 & $\mathrm{Sp}-\mathrm{Su}$ & Coelho \& Santos (1993) \\
\hline $21^{\circ} 37^{\prime} \mathrm{S}, 41^{\circ} 00^{\prime} \mathrm{W}$ & $\mathrm{SE}(\mathrm{RJ})$ & Jun 2005-May 2010 & 12.0 & 22.0 & Sp-Su-Wi & Fernandes et al. (2011) \\
\hline $23^{\circ} 26^{\prime} \mathrm{S}, 45^{\circ} 02^{\prime} \mathrm{W}$ & SE (SP) & Oct $1992-$ Sep 1993 & $68.0^{\mathrm{a}}$ & $83.2^{\mathrm{a}}$ & $\mathrm{Sp}-\mathrm{Fa}$ & Nakagaki \& Negreiros-Fransozo (1998) \\
\hline $23^{\circ} 26^{\prime} \mathrm{S}, 45^{\circ} 02^{\prime} \mathrm{W}$ & $\mathrm{SE}(\mathrm{SP})$ & Sep 1995-Aug 1996 & na & na & $\mathrm{Sp}-\mathrm{Fa}$ & Castro et al. (2005) \\
\hline $23^{\circ} 48^{\prime} \mathrm{S}, 45^{\circ} 23^{\prime} \mathrm{W}$ & $\mathrm{SE}(\mathrm{SP})$ & Jan 1998-Jun 2003 & 15.6 & 17.9 & $\mathrm{Sp}-\mathrm{Su}$ & A. L. Castilho et al. (unpubl.) \\
\hline $23^{\circ} 26^{\prime} \mathrm{S}, 45^{\circ} 02^{\prime} \mathrm{W}$ & SE (SP) & Jul 2005-Jun 2007 & 13.3 & 13.5 & $\mathrm{Sp}-\mathrm{Su}$ & G. S. Heckler et al. (unpubl.) \\
\hline \multirow[t]{2}{*}{$23^{\circ} 29^{\prime} \mathrm{S}, 45^{\circ} 10^{\prime} \mathrm{W}$} & $\mathrm{SE}(\mathrm{SP})$ & Nov 2008-Dec 2009 & $12.8^{\mathrm{b}}$ & $13.2^{\mathrm{b}}$ & $\mathrm{Sp}-\mathrm{Fa}$ & Present study \\
\hline & & & $16.3^{\mathrm{c}}$ & $17.3^{\mathrm{c}}$ & $\mathrm{Sp}-\mathrm{Fa}$ & \\
\hline $26^{\circ} 23^{\prime} \mathrm{S}, 48^{\circ} 36^{\prime} \mathrm{W}$ & $\mathrm{S}(\mathrm{SC})$ & Mar 1996-Feb 1997 & 13.9 & 17.1 & na & Branco et al. (1999) \\
\hline $26^{\circ} 47^{\prime} \mathrm{S}, 48^{\circ} 38^{\prime} \mathrm{W}$ & $\mathrm{S}(\mathrm{SC})$ & 1996-1997; 1999-2001 & 14.2 & 16.0 & $\mathrm{Sp}-\mathrm{Fa}$ & Branco (2005) \\
\hline
\end{tabular}

than those reported by previous studies in the same region (northern coast of São Paulo State) but before the establishment of the MPA and along the Brazilian coast (Table 3).

Importantly, various past studies have not taken into account juveniles when estimating $\mathrm{CL}_{50}$. Some of these studies have (inappropriately) categorized adult males and females with spent terminal ampullae and ovaries, respectively, as juveniles. This misclassification of adult males and females as juveniles most certainly overestimates $\mathrm{CL}_{50}$ in Xiphopenaeus kroyeri. If we had considered only adult individuals in our calculations, the estimated $\mathrm{CL}_{50}$ would correspond to 16.3 and $17.3 \mathrm{~mm}$ in males and females, respectively (Table 3); these values are similar to those reported by previous studies but incorrect. Overall, uncertainty in size at maturity might have important implications for fisheries stock assessment, including those targeting crustaceans (J. Anderson et al. unpubl.). Agestructured models built to evaluate the effect of uncertainty in $\mathrm{CL}_{50}$ on stocks of exploited crustaceans have shown that even with low exploitation rates, an overestimation of such size can affect values of the 'spawning potential ratio' so that the models incorrectly indicate stock overexploitation. Alternately, an underestimation of size at maturity can cause the failure of models to recognize stock overexploitation when, on reality, overexploitation is indeed taking place (J. Anderson et al. unpubl.). We argue in favor of studies constructing agestructured models to evaluate the effect of uncertainty in $\mathrm{CL}_{50}$ on population assessments of $X$. kroyeri.

\section{Factors correlating with reproduction and recruitment}

Xiphopenaeus kroyeri reproduced continuously but with dissimilar intensity throughout the year. In this study 2 well defined annual reproductive peaks were detected, one during late summer-early fall and a second peak occurring in spring. This reproductive dynamic agrees remarkably well with that reported for other populations of $X$. kroyeri in the northeastern, southeastern and southern regions of the Brazilian coast (e.g. Coelho \& Santos 1993, Nakagaki \& Negreiros-Fransozo 1998, Branco 2005, Castro et al. 2005, Fernandes et al. 2011, A. L. Castilho et al. unpubl., G. S. Heckler et al. unpubl.; Table 3). Interestingly, this similarity in reproductive schedules among populations supports the notion that continuous reproduction with dissimilar intensity (i.e. with breeding peaks in spring and fall) is the rule rather than the exception in Penaeoidae shrimps from tropical and subtropical environments (see Garcia 1988).

Our statistical analyses (CCA) demonstrated a positive correlation between temperature and the abundance of reproductive females during the study period. Importantly, changes in reproductive intensity occurred concomitantly with changes in water temperature during this study; the maximum reproductive activity in females of Xiphopenaeus kroyeri (determined by the relative abundance of individuals with developing and developed ovaries that were close to spawning; Bauer \& Rivera Vega 1992) occurred at a time of the year when the maximum mean values of temperature $\left(>25^{\circ} \mathrm{C}\right)$ were recorded at the study site. Thus, temperature appears to drive reproduction in 
$X$. kroyeri, and sudden increases in temperature might be triggering reproduction in this species.

Temperature has been suggested to affect gonad maturation and/or spawning in other Penaeoidea shrimps (e.g. Sastry 1983, Garcia 1988, Dall et al. 1990, Bauer 1992, Bauer \& Rivera Vega 1992, Bauer \& Lin 1994, Costa \& Fransozo 2004, Castilho et al. 2007a,b, 2008b,c, 2012, A. L. Castilho et al. unpubl.). In Xiphopenaeus kroyeri, high temperature might speed up gametogenesis, and sudden increases in temperature (as observed during the summer, early fall and spring in this study) might also signal to parental females favorable conditions in the water column for egg production and spawning. Importantly, the highest reproductive intensity of $X$. kroyeri observed in this study not only occurred when temperature was high but also at a time of the year (spring and summer) when the SACW intrudes into the continental shelf (Pires 1992). This water mass transports nutrients to the studied region due to its high nitrogen to phosphorus ratio ( $\mathrm{N}: \mathrm{P}=16: 1)$ that favors primary productivity (Aidar et al. 1993, Odebrecht \& Castello 2001). Food availability for larvae (e.g. primary and/or secondary productivity) is also recognized as another important condition affecting reproduction and spawning in marine invertebrates, including other shrimps (Thorson 1950, Sastry 1983, Bauer 1992, Bauer \& Rivera Vega 1992). High nutrient load entering to the system due to the intrusion of the SACW and increased primary productivity (Pires-Vanin \& Matsuura 1993) is expected to boost larval condition and/or survival of $X$. kroyeri at Fortaleza Bay.

Sediment characteristics affected the abundance of adult individuals of Xiphopenaeus kroyeri at Fortaleza Bay. The positive correlation between sediment type (fine and very fine sand and silt/clay) and abundance of $X$. kroyeri demonstrated by the CCA coincides with that reported by previous studies; shrimps mostly inhabit fine/very fine sand and/or silt/clay along the Brazilian coast (Costa et al. 2000, 2007, 2011, Fransozo et al. 2002, Castilho et al. 2008a, Simões et al. 2010, Freire et al. 2011). Adults of various other Penaeoidea shrimp usually inhabit fine rather than coarse sediments (Dall et al. 1990). Most probably, finer sediments facilitate burrowing in adult shrimps by reducing energy requirements for excavation (Dall et al. 1990, Freire et al. 2011). Indeed, experimental studies have shown that shrimps excavate more rapidly in sediment between $62.00 \mu \mathrm{m}$ and $1.00 \mathrm{~mm}$ (Dall et al. 1990, Freire et al. 2011). Fine sediments might also allow adult shrimps to excavate deeper and escape from potential predators (Dall et al. 1990, Freire et al. 2011).
Interestingly, the abundance of juvenile shrimps was not affected by sediment type; it correlated positively with algae and plant biomass floating near the bottom at Fortaleza Bay. The same relationship between juvenile abundance and such algae and plant biomass was reported before for Xiphopenaeus kroyeri at Ubatuba Bay, northern coast of São Paulo State (e.g. Castro et al. 2005). According to previous studies (Dall et al. 1990, Simões et al. 2010), juvenile shrimps are poor excavators, even in fine sediment. Consequently, they usually settle in shallow water environments rich in detritus, such as seagrass beds, mangrove swamps, or floating sargassum (Garcia 1988). Herein, we propose that large amounts of algae and plants floating near the marine floor, which are associated with local hydrodynamic conditions and proximity to the continent, as well as the input from the small rivers Escuro and Comprido, might provide a nursery ground for $X$. kroyeri in the study region (see also Castro et al. 2005). Such debris could provide protection for juvenile shrimps against potential predators, as this material most probably increases environmental heterogeneity in structurally simple soft bottom habitats (Fransozo et al. 2009a, Almeida et al. 2012). However, additional studies on the ecology of juveniles of $X$. kroyeri both in shallow and deeper nursery grounds is warranted as these might help to understand the early benthic life history of this shrimp and predict adult stock abundance along the Brazilian coast.

\section{Reproductive biology and recruitment in an MPA}

Overall, our literature review suggests that there are no major differences in the reproductive biology and recruitment schedule of Xiphopenaeus kroyeri between Fortaleza Bay and several other localities along the Brazilian coast (see Table 3). However, these similarities among different populations of $X$. kroyeri distributed over $>1000 \mathrm{~km}$ of coast-which encompasses $\sim 10 \%$ of the distribution range of this species in the south Caribbean and southwestern Atlantic-are very important, especially when considering the differences in methodology among studies (e.g. fishing gear, catching effort, and statistical analyses; see references in Table 3). Two aspects emerging from this comparison among populations deserve attention as we believe they have important implications for the future management of the species, not only in the Brazilian coast but in the central and southwestern Atlantic. 
First, considering previously reported information on the abundance of this shrimp throughout the northern coast of São Paulo State before the establishment of the MPA, Fortaleza Bay appears to sustain larger populations of Xiphopenaeus kroyeri than adjacent areas: CPUE $=61.9$ shrimp km$~^{-2}$ in Ubatuba Bay (Nakagaki et al. 1995), 72.5 shrimp km$~^{-2}$ in Ubatumirim, Ubatuba and Mar Virado bays (Costa et al. 2007), 45.2 shrimp $\mathrm{km}^{-2}$ in Ubatuba and Caraguatatuba regions (Castilho et al. 2008a) versus 112.3 shrimp $\mathrm{km}^{-2}$ in Fortaleza Bay (this study). The above and the occurrence of abundant juveniles in the studied locality suggests that Fortaleza Bay might serve as a 'seed production' locality and nursery ground that might help in the future to replenish nearby (and also far away, see below) fishing grounds of the species during the next decades.

Second, the similarity in reproductive schedules among populations, that in some cases are located thousands of $\mathrm{km}$ apart, suggests the existence of an open meta-population with considerable connectivity in the southwestern Atlantic. The relative long larval period reported for this species ( 16 d; Fransozo et al. $2009 b)$ supports the idea of considerable connectivity among distantly located populations hundreds and thousands of $\mathrm{km}$ apart. The study of meso-scale oceanographic processes (Cowen et al. 2000) and the phylogeography of Xiphopenaeus kroyeri along the Brazilian coast (Voloch \& Solé-Cava 2005, Gusmão et al. 2006, Francisco et al. 2009) might help to reveal the extent of connectivity among populations, that in turn, will help guide the establishment of sound management strategies in this widely distributed species.

Acknowledgements. The authors are grateful to the Fundação de Amparo à Pesquisa do Estado de São Paulo (FAPESP) and to the Conselho Nacional de Desenvolvimento Científico e Tecnológico (CNPq) for providing financial support. We are thankful to the NEBECC co-workers for their help during the fieldwork, and to Dr. M. M. Mischan, volunteer professor of the Biostatistics Department at Universidade Estadual Paulista, for her help with analyses performed in the SAS Software. All sampling in this study was conducted in compliance with current applicable state and federal laws. J.A.B. is most grateful to M. L. Negreiros Fransozo, A. Fransozo, P. Araujo, A. Oliveira de Almeida, R. Cunha Lima and the Sociedade Brasileira de Carcinologia that made his visit to Brazil possible during 2010 and this collaboration. This is Contribution No. 894 of the Smithsonian Marine Station at Fort Pierce.

\section{LITERATURE CITED}

Ab'Saber AN (1955) Contribuições à geomorfologia do litoral paulista. Rev Bras Geogr 17:3-37

Aidar E, Gaeta SA, Gianesenella-Galvão SMF, Kutner MBB,
Teixeira C (1993) Ecossistema costeiro subtropical: nutrientes dissolvidos, fitoplâncton e clorofila-a e suas relações com as condições oceanográficas na região de Ubatuba, SP. Publ Espec Inst Oceanogr 10:9-43

$>$ Almeida AC, Fransozo A, Teixeira GM, Hiroki KAN, Furlan M, Bertini G (2012) Ecological distribution of the shrimp Nematopalaemon schmitti (Crustacea: Decapoda: Caridea) in three bays on the south-eastern coast of Brazil. Afr J Mar Sci 34:93-102

> Bauer RT (1986) Phylogenetic trends in sperm transfer and storage complexity in decapod crustaceans. J Crustac Biol 6:313-325

Bauer RT (1991) Sperm transfer and storage structures in penaeoid shrimps: a functional and phylogenetic perspective. In: Bauer RT, Martin JW (eds) Crustacean sexual biology. Columbia University Press, New York, NY, p 183-207

Bauer RT (1992) Testing generalizations about latitudinal variation in reproduction and recruitment patterns with sicyoniid and caridean shrimp species. Invertebr Reprod Dev 22:193-202

- Bauer RT, Cash CE (1991) Spermatophore structure and anatomy of the ejaculatory duct in Penaeus setiferus, $P$. duorarum, and P. aztecus (Crustacea: Decapoda): homologies and functional significance. Trans Am Microsc Soc 110:144-162

Bauer RT, Lin J (1994) Temporal patterns of reproduction and recruitment in the marine shrimps Trachypenaeus similis (Smith) and T. constrictus (Stimpson) (Crustacea: Decapoda) from the Northcentral Gulf of Mexico. J Exp Mar Biol Ecol 182:205-222

Bauer RT, Rivera Vega LW (1992) Pattern of reproduction and recruitment in two sicyoniid shrimp species (Decapoda, Penaeoidea) from a tropical seagrass habitat. J Exp Mar Biol Ecol 161:223-240

- Branco JO (2005) Biologia e pesca do camarão sete-barbas Xiphopenaeus kroyeri (Heller) (Crustacea, Penaeidae), na Armação de Itapocoroy, Penha, Santa Catarina, Brasil. Rev Bras Zool 22:1050-1062

Branco JO, Lunardon-Branco MJ, Souto FX, Guerra CR (1999) Estrutura populacional do camarão sete-barbas Xiphopenaeus kroyeri (Heller, 1862), na Foz do Rio Itajaí-Açú, Itajaí, SC, Brasil. Braz Arch Biol Technol 42: 115-126

Campos BR, Dumont LFC, D'Incao F, Branco JO (2009) Ovarian development and length at first maturity of the sea-bob-shrimp Xiphopenaeus kroyeri (Heller) based on histological analysis. Nauplius 17:9-12

Castilho AL, Costa RC, Fransozo A, Boschi EE (2007a) Reproductive pattern of the South American endemic shrimp Artemesia longinaris (Decapoda, Penaeidae), off the coast of São Paulo state, Brazil. Rev Biol Trop 55: $39-48$

Castilho AL, Gavio MA, Costa RC, Boschi EE, Bauer RT, Fransozo A (2007b) Latitudinal variation in population structure and reproduction pattern of the endemic South American shrimp Artemesia longinaris (Decapoda: Penaeoidea). J Crustac Biol 27:548-552

Castilho AL, Pie MR, Fransozo A, Pinheiro AP, Costa RC (2008a) The relationship between environmental variation and species abundance in shrimp community (Crustacea, Decapoda, Penaeoidea) in southeastern Brazil. J Mar Biol Assoc UK 88:119-123

Castilho AL, Costa RC, Fransozo A, Negreiros-Fransozo ML (2008b) Reproduction and recruitment of the South 
American red shrimp, Pleoticus muelleri (Crustacea: Solenoceridae), from the southeastern coast of Brazil. Mar Biol Res 4:361-368

Castilho AL, Furlan M, Costa RC, Fransozo V (2008c) Reproductive biology of the rock shrimp Sicyonia dorsalis (Decapoda: Penaeoidea) from the southeastern coast of Brazil. Invertebr Reprod Dev 52:59-68

Castilho AL, Wolf MR, Simões SM, Bochini GL, Fransozo V, Costa RC (2012) Growth and reproductive dynamics of the South American red shrimp, Pleoticus muelleri (Crustacea: Solenoceridae), from the southeastern coast of Brazil. J Mar Syst 105-108:135-144

Castro RH, Costa RC, Fransozo A, Mantelatto FLM (2005) Population structure of the seabob shrimp Xiphopenaeus kroyeri (Heller, 1862) (Crustacea: Penaeoidea) in the littoral of São Paulo, Brazil. Sci Mar 69:105-112

Castro-Filho BM, Miranda LB, Myao SY (1987) Condições hidrográficas na plataforma continental ao largo de Ubatuba: variações sazonais e em média escala. Bol Inst Oceanogr 35:135-151

Coelho PA, Santos MCF (1993) Época de reprodução do camarão sete-barbas, Xiphopenaeus kroyeri (Heller, 1862) (Crustacea, Decapoda, Penaeidae) na região de Tamandaré, PE. Bol Tec Cient CEPENE 1:171-186

Costa RC, Fransozo A (2004) Reproductive biology of the shrimp Rimapenaeus constrictus (Decapoda, Penaeidae) in the Ubatuba region of Brazil. J Crustac Biol 24: 274-281

Costa RC, Fransozo A, Mantelatto FLM, Castro RH (2000) Occurrence of shrimp species (Crustacea: Decapoda: Natantia: Penaeidea and Caridea) in Ubatuba Bay, Ubatuba, SP, Brazil. Proc Biol Soc Wash 113:776-781

Costa RC, Fransozo A, Freire FAM, Castilho AL (2007) Abundance and ecological distribution of the 'sete-barbas' shrimp Xiphopenaeus kroyeri (Heller, 1862) (Decapoda: Penaeoidea) in three bays of the Ubatuba region, southeastern Brazil. Gulf Caribb Res 19:33-41

Costa RC, Heckler GS, Simões SM, Lopes M, Castilho AL (2011) Seasonal variation and environmental influences in abundance of juveniles of the seabob shrimp Xiphopenaeus kroyeri (Heller, 1862) in southeastern Brazil. In: Pessani D, Froglia C, Biaggi E, Nurra N and others (eds) Behaviour, ecology, fishery. Museo Regionale di Scienze Naturali di Torino, Turin, p 45-56

Cowen RK, Kamazima MML, Sponaugle S, Paris CB, Olson DB (2000) Connectivity of marine populations: open or closed? Science 287:857-859

D'Incao F, Valentini H, Rodrigues LF (2002) Avaliação da pesca de camarões nas regiões sudeste e sul do Brasil: 1965-1999. Atlantica 24:103-116

Dall W, Hill BJ, Rothlisberg PC, Sharples DJ (1990) The biology of the Penaeidae. Academic Press, San Diego, CA

Díaz AC, Fernández Gimenez AV, Petriella AM, Fenucci JL (2002) Morphological and functional study of the male reproductive tract in the shrimp Pleoticus muelleri Bate (Decapoda, Penaeoidea). Invertebr Reprod Dev 42:69-74

FAO (2011) Global capture production 1950-2009. FIGIS Fisheries Global Information System, available at: www. fao.org/figis/servlet/TabSelector?tb_ds=Capture\&tb_mode $=$ TABLE\&tb_act=SELECT\&tb_grp=SPECIES $($ accessed 12 Jan 2012)

Fernandes LP, Silva AC, Jardim LP, Keunecke KA, Di Beneditto APM (2011) Growth and recruitment of the Atlantic seabob shrimp Xiphopenaeus kroyeri (Heller, 1862) (Decapoda, Penaeidae) on the coast of Rio de
Janeiro, southeastern Brazil. Crustaceana 84:1465-1480

Francisco AK, Pinheiro AP, Silva TB, Galetti PM Jr (2009) Isolation and characterization of microsatellites in three overexploited penaeid shrimp species along the Brazilian coastline. Conserv Genet 10:563-566

Fransozo A, Costa RC, Pinheiro MAA, Santos S, Mantelatto FLM (2000) Juvenile recruitment of the seabob Xiphopenaeus kroyeri (Heller, 1862) (Decapoda, Penaeidea) in Fortaleza Bay, Ubatuba, SP, Brazil. Nauplius 8:179-184

Fransozo A, Costa RC, Mantelatto FLM, Pinheiro MAA, Santos S (2002) Composition and abundance of shrimp species (Penaeidea and Caridea) in Fortaleza Bay, Ubatuba, São Paulo, Brazil. In: Briones EE, Alvarez F (eds) Modern approaches to the study of Crustacea. Kluwer Academic Publishers, Dordrecht, p 117-123

Fransozo V, Castilho AL, Freire FAM, Furlan M, Almeida AC, Teixeira GM, Baeza JA (2009a) Spatial and temporal distribution of the shrimp Nematopalaemon schmitti (Decapoda, Caridea, Palaemonidae) at a subtropical enclosed bay in South America. J Mar Biol Assoc UK 89: 1581-1587

Fransozo A, Rodríguez A, Negreiros-Fransozo ML (2009b) Desarrollo larvario de Xiphopenaeus kroyeri (Heller, 1862) cultivados en el laboratorio. In: Montero GG, Chabalina L, Márquez AF and others (eds) Proc 13th Congr Latinoam de Cienc del Mar, La Habana, Cuba, p 262

> Fransozo V, Santos DC, López-Greco LS, Bolla EA Jr (2011) Development of secondary sexual characters in the seabob shrimp Xiphopenaeus kroyeri (Heller, 1862) (Crustacea, Decapoda, Penaeidae): a scanning electron microscope study. Invertebr Reprod Dev 55:6-15

Freire FAM, Luchiari AC, Fransozo V (2011) Environmental substrate selection and daily habitual activity in Xiphopenaeus kroyeri shrimp (Heller, 1862) (Crustacea: Penaeoidea). Indian J Geo Mar Sci 40:325-330

Garcia S (1988) Tropical penaeid prawns. In: Gulland JA (eds) Fish population dynamics, 2nd edn. John Wiley \& Sons, Chichester, p 219-249

Gillett R (2008) Global study of shrimp fisheries. FAO Fisheries Technical Paper No. 475, Rome

> Gusmão J, Lazoski C, Monteiro FA, Solé-Cava AM (2006) Cryptic species and population structuring of the Atlantic and Pacific seabob shrimp species, Xiphopenaeus kroyeri and Xiphopenaeus riveti. Mar Biol 149:491-502

Holthuis LB (1980) Shrimps and prawns of the world: an annotated catalogue of species of interest to fisheries. FAO Fisheries Synopsis, Rome

IBAMA/CEPSUL (2006) Relatório da reunião técnica de análise da pescaria do camarão sete-barbas (Xiphopenaeus kroyeri). Ministério do Meio Ambiente, Itajaí

Kindt R, Coe R (2005) Tree diversity analysis. A manual and software for some common statistical methods for biodiversity and ecological analysis. World Agroforestry Center, Nairobi

Magliocca A, Kutner AS (1965) Sedimentos de fundo da Enseada do Flamengo, Ubatuba, SP. Contrib Inst Oceanogr 198:1-15

> Mahiques MM (1995) Dinâmica sedimentar atual nas enseadas da região de Ubatuba, Estado de São Paulo. Bol Inst Oceanogr 43:111-122

> Mahiques MM, Tessler MG, Furtado VV (1998) Characterization of energy gradient in enclosed bays of Ubatuba region, South-eastern Brazil. Estuar Coast Shelf Sci 47: 431-446

Matsuura Y (1995) Exploração pesqueira. In: Ministério do 
Meio Ambiente (ed) Os ecossistemas brasileiros e os principais macrovetores de desenvolvimento: subsídios ao planejamento da gestão ambiental. Ministério do Meio Ambiente, dos Recursos Hídricos e da Amazônia Legal, Brasília, p 42-48

Nakagaki JM, Negreiros-Fransozo ML (1998) Population biology of Xiphopenaeus kroyeri (Heller, 1862) (Decapoda: Penaeidae) from Ubatuba Bay, São Paulo, Brazil. J Shellfish Res 17:931-935

Nakagaki JM, Negreiros-Fransozo ML, Fransozo A (1995) Composição e abundância de camarões marinhos (Crustacea: Decapoda: Penaeidae) na Enseada de Ubatuba, Ubatuba SP. Arq Biol Tecnol 38:583-591

Odebrecht C, Castello JP (2001) The convergence ecosystem in the Southwest Atlantic. Ecol Stud 144:147-165

Peixoto S, Cavalli RO, D'Incao F, Milach AM, Wasielesky W (2003) Ovarian maturation of wild Farfantepenaeus paulensis in relation to histological and visual changes. Aquacult Res 34:1255-1260

Pinheiro MAA, Fransozo A (1998) Sexual maturity of the speckled swimming crab Arenaeus cribrarius (Lamark, 1818) (Decapoda, Brachyura, Portunidae), in Ubatuba littoral, São Paulo State, Brazil. Crustaceana 71:434-452

Pires AMS (1992) Structure and dynamics of benthic megafauna on the continental shelf offshore of Ubatuba, southeastern, Brazil. Mar Ecol Prog Ser 86:63-76

Pires-Vanin AMS, Matsuura Y (1993) Estrutura e função do ecossistema de plataforma continental da região de Ubatuba, Estado de São Paulo: uma introdução. Bol Inst Oceanogr 10:1-8

R Development Core Team (2008) R: a language and environment for statistical computing. R Foundation for Statistical Computing, Vienna

Sastry AN (1983) Ecological aspects of reproduction. In: Vernberg FJ, Vernberg WB (eds) The biology of Crus-

Editorial responsibility: Riccardo Cattaneo-Vietti, Genova, Italy tacea: environmental adaptations. Academic Press, New York, NY, p 179-270

Simões SM, Costa RC, Fransozo A, Castilho AL (2010) Diel variation in abundance and size of the seabob shrimp Xiphopenaeus kroyeri (Crustacea, Penaeoidea) in the Ubatuba region, Southeastern Brazil. An Acad Bras Cienc 82:369-378

Suguio K (1973) Introdução à sedimentologia. Edgar Blücher, São Paulo Ter Braak CJF (1986) Canonical correspondence analysis: a new eigenvector technique for multivariate direct gradient analysis. Ecology 67:1167-1179

Ter Braak CJF (1986) Canonical correspondence analysis: a new eigenvector technique for multivariate direct gradient analysis. Ecology 67:1167-1179

Thorson G (1950) Reproductive and larval ecology of marine bottom invertebrates. Biol Rev Camb Philos Soc 25:1-45

Valentini H, D'Incao F, Rodrigues LF, Neto JER, Domit LG (1991) Análise da pesca do camarão sete-barbas (Xiphopenaeus kroyeri) nas regiões Sudeste e Sul do Brasil. Atlantica 13:171-177

Vasconcellos M, Diegues AC, Salles RR (2007) Limites e possibilidades na gestão da pesca artesanal costeira. In: Costa AL (ed) Nas redes da Pesca Artesanal. PNUD/ IBAMA, Brasília, p 15-83

Vasconcellos M, Diegues AC, Kalikoski DC (2011) Coastal fisheries of Brazil. In: Salas S, Chuenpagdee R, Charles A, Seijo JC (eds) Coastal fisheries of Latin America and the Caribbean. FAO Fish Aquac Tech Paper No. 544, Rome, p 73-116

> Voloch CM, Solé-Cava AM (2005) Genetic structure of the sea-bob shrimp (Xiphopenaeus kroyeri Heller, 1862; Decapoda, Penaeidae) along the Brazilian southeastern coast. Genet Mol Biol 28:254-257

Wentworth CK (1922) A scale of grade and class terms for clastic sediments. J Geol 30:377-392

Submitted: May 9, 2012; Accepted: July 17, 2012

Proofs received from author(s): October, 2012 